\title{
RISK EFFECT OF WATER TREATMENT SLUDGE ON BIOACCUMULATION OF HEAVY METALS IN WATER, FISH (OREOCHROMIS NILOTICUS, AND CLARIAS GARIEPINUS) FROM RIVER CHANCHAGA MINNA NIGER STATE, NIGERIA
}

\author{
Oguh C. $\mathbf{E}^{1 *}$, Joseph P. $\mathrm{S}^{2}$, Osuji C. $\mathrm{A}^{1}$, Ubani C. $\mathrm{S}^{1}$, Okunowo W. $\mathrm{O}^{3}$ \\ ${ }^{1}$ Department of Biochemistry, University of Nigeria, Nsukka, Enugu State, Nigeria. \\ ${ }^{2}$ Department of Biochemistry, Ibrahim BadamasiBabangida University, Lapai, Niger State, Nigeria \\ ${ }^{3}$ Department of Biochemistry, College of Medicine, University of Lagos, Akoka-Yaba, Lagos, Nigeria \\ http://doi.org/10.35410/IJAEB.2019.4431
}

\begin{abstract}
The safe disposal of Water Treatment Sludge has become one of the main environmental concerns throughout the world due to the enormous quantity of sludge generated. Typically, the sludge discharge to river bodies affect fish species. This study investigates the effect of water treatment sludge on bioaccumulation of heavy metals in water, fish (Oreochromisniloticus, and Clariasgariepinus) from river ChanchagaMinna Niger State, Nigeria and the human health risk associated with their consumption. Fishes and water samples were collected from river contaminated with sludge (River Chanchaga) and other samples from a private farm where there were no sludge served as control (Makolo farm). The water samples were collected and analyzed for physicochemical properties(dissolved oxygen, electrical conductivity, $\mathrm{pH}$ and temperature) using a standard method and concentrations of heavy metalboth in fish and water, As, Cd, Cr, $\mathrm{Cu}, \mathrm{Hg}$ and $\mathrm{Pb}$ were analyze using Atomic Absorption Spectroscopy (AAS). The Bioaccumulation factor and potential risk (Daily intake, health risk index and Hazard index) from the consumption of these fish was assessed using standard methods and formula. All the samples collected were digested using a modified procedure from the Association of Official Analytical Chemists (AOAC) and were subsequently analyzed using Atomic Absorption Spectroscopy. The result of the physicochemical properties and Heavy metal concentration in water shows a significant different $(\mathrm{P}<0.05)$ between the $\mathrm{C}$. river and $\mathrm{M}$. pond. The mean of concentration of Heavy Metals (As, $\mathrm{Cd}, \mathrm{Cr}, \mathrm{Cu}, \mathrm{Hg}$, and $\mathrm{Pb}$ ) in O.niloticus, and C.gariepinus from C. river were 2.66, 3.72, 1.84, 2.23, 3.68, 2.88, and 2.83, 3.87, 2.12, 2.66, 3.87, $2.61 \mathrm{mg} / \mathrm{kg}$ respectively and for M.pond were $0.69,0.98,1.04,0.83,0.54,1.00$ and $0.79,0.98,1.16,1.02$, $0.87,1.16 \mathrm{mg} / \mathrm{kg}$ respectively. Fishes in $\mathrm{C}$. river elicited higher $(\mathrm{P}<0.05)$ heavy metals concentrations compare to Fishes in $\mathrm{M}$. pond. The values were all greater than themaximum permissible limit of heavy metal in fish $0.01,0.05,1.5,0.5,0.01$ and $0.3 \mathrm{mg} / \mathrm{kg}$ respectively recommended by $\mathrm{FAO} / \mathrm{WHO}$ except $\mathrm{Cr}$ in the control farm which is within the limit. The result of health risk assessment shows that fishes from $\mathrm{C}$. river have a higher risk from the daily intake, health risk index and hazard index with average values greater than one (2.845) and compared to fish in $\mathrm{M}$. pond with average less than one (0.64). The study concludes that water treatment sludge discharge in Chanchagariverhave deleterious effect on fishes and also bioaccumulate heavy metals in the fish. The risk assessment shows that fish in C.River are contaminated with heavy metals and could pose health risk from heavy metalContamination when consume.
\end{abstract}


Vol. 4, No. 05; 2019

ISSN: $2456-8643$

Keywords: Clariasgariepinus, Oreochromisniloticus, Heavy Metals, Water, Risk Assessment

\section{INTRODUCTION}

In Niger State, Nigeria because of rapid growing population, water treatment plants are facing the problem of treating highly loaded raw water withdissolved and suspended particles and have to use diverse chemicals in order to obtain drinking water which meets the fast growing population and acceptable health standards. Due to feeding and living in the aquatic environments fish aremostly vulnerable and heavily exposed to pollution becausethey cannot escape from the detrimental effects of pollutants i.e. they are cold blooded animals and survive only on water (Yarsanet al., 2013; Mahboobet al., 2014). In aquatic environments, heavymetals(HMs) pollution results from direct atmospheric deposition, geologicweathering or through the discharge of agricultural, municipal,residential or industrial waste products, also via wastewater treatmentplants. Fishes are considered to be most significantbiomonitors in aquatic systems for the estimation of metal pollutionlevel (Authman, 2008). Fish have been used for many years as indicators of environmental pollution status, and, thus, they are regarded as good indicators of metal pollution in marine environments (Marcus et al., 2013).Studies from the field and laboratory works showed that accumulation of HMs in a tissue is mainly dependent on water concentrations of metals and exposure period; although some other environmental factors such as water temperature, oxygen concentration, $\mathrm{pH}$, hardness, salinity, alkalinity and dissolved organic carbon may affect and play significant roles in metal's accumulation and toxicity to fish (Jitaret al., 2014; Authmanet al., 2015). The pollutants such as HMs bioaccumulate in food chain and cause the antagonistic effects and even death, so fish among other animals are used to determine the health condition of aquatic ecosystem. Bioaccumulation of heavy metals means an increase in the degree of a metals in a living organism over time, compared with chemical's level in the environment.

Water treatment is the application of physical and chemical process to a water supply to remove taste, colour, odour, dirt and debris, to reduce hard elements, salt and to destroy harmful organisms. Consequently sludge produced from water purification processes contain high concentrations of those chemical removed by the purification processes (Uwimanaet al., 2010). Water treatment sludge (WTS) is produced in conventional drinking-water treatment processes as sedimentation including suspended and dissolved solids, organic matter, and other suspensions from the water. Due to these facts, the safe disposal of WTS has become one of the main environmental concerns throughout the world due to the enormous quantity of sludge generated. Typically, this WTS is discharge and channel back to the river close to the treatment and aquatic life such as phytoplankton, zooplankton, and crustacean, macro-algae and fish species are effected (Oguh et al., 2019a).

Fish are located at the end of the aquatic food chain and may accumulate metals and pass them to human beings through food causing chronic or acute diseases (Al-Yousufet al., 2000). Aquatic systems are one facet of the impact of toxic substances on the natural environment (Mohammed et al., 2016). The most important pollutants in aquatic life are HMs because of their toxicity, accumulation and bio-magnification by marine creatures. The high level of heavy metals in the river could indicate similar concentration in fishes by accumulation at concentrations causing 
serious risk to human health through food chain when consumed. More important is that the very young stages of fish (larvae and juveniles) grow up in the near shore zone, where the water quality is heavily affected by the raw sludge (Zaqoot et al., 2017). Accumulation pattern of HMs varies from fish species, some fish accumulate more heavy metal than others. The toxic effects of HMs can affect the individual growth rates, physiological functions, reproduction, and mortality in fish. Metals are accumulate in fish bodies by three possible ways: gills, digestive track and body surface. The gills are considered as the significant site for direct uptake of metals from the water (Beijer and Jernelov, 1986), HMs in fish come mainly from their diet, though the body surface is normally estimated to take minor part in uptake of heavy metals in fish (Selda and Nurşah, 2012).Fish and bivalve molluscs are used in bioaccumulation tests because they arehigher tropic level organisms and are usually eaten by human (Olaifaet al., 2014).

The term heavy metal refers to any metallic chemical element that has a relatively high density greater than $5 \mathrm{~g} / \mathrm{cm} 3$ and is toxic or poisonous at low concentrations. Examples of heavy metals include mercury $(\mathrm{Hg})$, cadmium $(\mathrm{Cd})$, arsenic $(\mathrm{As})$, chromium $(\mathrm{Cr})$, thallium $(\mathrm{Ti})$ and lead $(\mathrm{Pb})$. The densities of $\mathrm{Pb}, \mathrm{Hg}$ and $\mathrm{Cd}$ are $11.4 \mathrm{gcm}-3,13.6 \mathrm{gms} / \mathrm{cubic} \mathrm{cms}$ and $8.65 \mathrm{gms} / \mathrm{cubic} \mathrm{cms}$ respectively. Recent researchers have found that even low levels of mercury, cadmium, lead, aluminum and arsenic can cause a wide variety of health problems (Hassaanet al., 2016).Heavy metals toxicity can result in damaged or reduced mental and central nervous function, lower energy levels and damage to blood composition, lungs, kidneys, liver and other vital organs. Long-term exposure may result in slowly progressing physical, muscular and neurological degenerative processes that mimic Alzheimer's disease, Parkinson's disease, muscular dystrophy and multiple sclerosis. Allergies are not common and repeated long-term contact with some metals may cause cancer. Metals such as cadmium, mercury, arsenic and lead are non-essential and therefore have toxic effects on living organisms such as damage to the renal and nervous systems of fish as well as gill damage (severe destructive pathological changes, i.e. structural lesions) (Barkaet al., 2001; Lars, 2003; Velchevaet al., 2010; Deore and Wagh, 2012).

Lead exerts its effect, physiologically and biochemically as a mimetic agent substituting for essential elements participating in metabolism such as calcium, iron and zinc. For instance, it directly interferes with zinc and iron in the biosynthesis of heme. Lead binds to different kinds of transport proteins including, metallothionein, transferrin, calmodulin and calcium-ATPase (WHO, 1989 and Corpaset al., 2002). The toxic effects of lead include anemia, proximal renal tubular damage, hypertension, cardiac disease, immune system suppression (antibody inhibition) and neurological damage. Lead severely damage the liver, kidneys, heart, brain, nerves and other organs. Exposure to $\mathrm{Pb}$ may also lead to reproductive disorders osteoporosis (brittle bone disease). $\mathrm{Pb}$ exposure causes increases in heart disease, anemia, high blood pressure, especially in men. Extensive exposure to $\mathrm{Pb}$ causes memory problems appropriations, behavioral disorders, and mental retardation while lesser levels of $\mathrm{Pb}$ damage the nerves and brain in fetuses and young children, resulting in lowered IQ and learning deficits (Kalayet al., 1999). Cadmium is highly toxic metal that was the cause of death, serious illness, rheumatoid arthritis (RA), full skeletal deformities, depressed growth, hypertension,diarrhea, vomiting, stomach problems, fractures in bone, damage to DNA, failure in reproduction and fertility, cause damage to nervous system, damage to immune system, cancer and fetal deformity (Mansour and Sidky, 2002). The 
International Agency Research on Cancer (IARC) has classified cadmium as human carcinogen (group I). It was found to be associated with prostate cancer and renal cell carcinoma (Stoeppler, 1991). Effect of chromium on humans by fish intakeare faded immune system, Skin diseases, Cause ulcer and upset stomach, Respiratory track problem, Alteration in genetic material, Lung cancer, liver and kidney damage and Death. Low exposure to chromium can irritage the skin and cause ulceration.Long term exposure can cause kidney and liver damage. It can also cause damage to circulatory and nerve tissues. Mercury toxicity include visual field construction, behavioral changes, memory loss, headaches, tremors, loss of fine motor control, spasticity, hair loss, mental retardation to fetus and fetal deformity, cerebral polsy, blindness, deafness and muscular rigidity (Clarkson et al., 2003). Arsenic is acutely toxic and intakes of large quantities result in adverse symptoms to gastrointestinal tract, severe disturbances of the cardiovascular and central nervous systems and eventually death. The latest WHO evaluation concludes that, exposure to arsenic via drinking water is causally related to cancer in the lungs, kidneys, urinary bladder and skin (WHO, 2001).

As a human food, Fish are considered as an excellent source of polyunsaturated fatty acids (predominantly omega-3 fatty acids), protein, Zn, iron and calcium (Toth and Brown, 1997). Seafood will be an even more important and safe source of food in future for protein and fatty acids for human intake and products made from aquaculture. Fish creates major sources of human beings food which is protein. Fish is a valuable and cheap food item, and also major part of the human diet. Sludge from water treatment plant, detergent, and dump sites present near the river water have high concentrations of heavy metals, which cause the disruption of the ecological balance of river water. Fish in such areas can be contaminated with HMs, consumption of this fishes by humans can cause accumulation of these metals in the food chain and many people could be at a risk of adverse health effect from consuming fishes in the river with WTS that is highly contaminated with toxic elements. Hence, this study was designed with the aim of determining the Effect of Water Treatment Sludge on Bioaccumulation of Heavy Metal (As, $\mathrm{Cd}, \mathrm{Cr}, \mathrm{Cu}, \mathrm{Hg}$, and $\mathrm{Pb}$ ) in Water, Oreochromisniloticus, and Clariasgariepinus Muscles from River ChanchagaMinna Niger State, Nigeria.

\subsection{MATERIALS AND METHODS}

Two commonly consumed fish; African Tilapia (Oreochromisniloticus), and African Catfish (Clariasgariepinus), were selected for the study. The fishes used for the study were harvested fresh from river Chanchaga,Minna Niger State.

\subsection{Study Areas}

The study was carried out in river close to Niger State water board and a private farm (Makolo farm) at Chanchaga, Bosso Local Government Area in North-central, Niger State of Nigeria from May to June 2019. Chanchaga is situated at 9'34' North latitude, 6 $6^{\circ} 33^{\prime}$ East longitude, with an area of $72 \mathrm{~km}^{2}$ and a population of 201,429 at the 2006 census (Figure 1).River Chanchaga is originated from fromTagwai Dam in Minna Niger State. It has a moderate climate with a very high temperature during the dry season and average rainfall during the rainy season. The river is use as water source in Niger State water board authority for water treatment. Makolo farm is a 
major agricultural enterprise in Chanchaga whoseoperations include fish farming. It supplies about 1 tonnes of fish per day and is locatedat Kangiwa road ChanchagaMinna, Niger State.

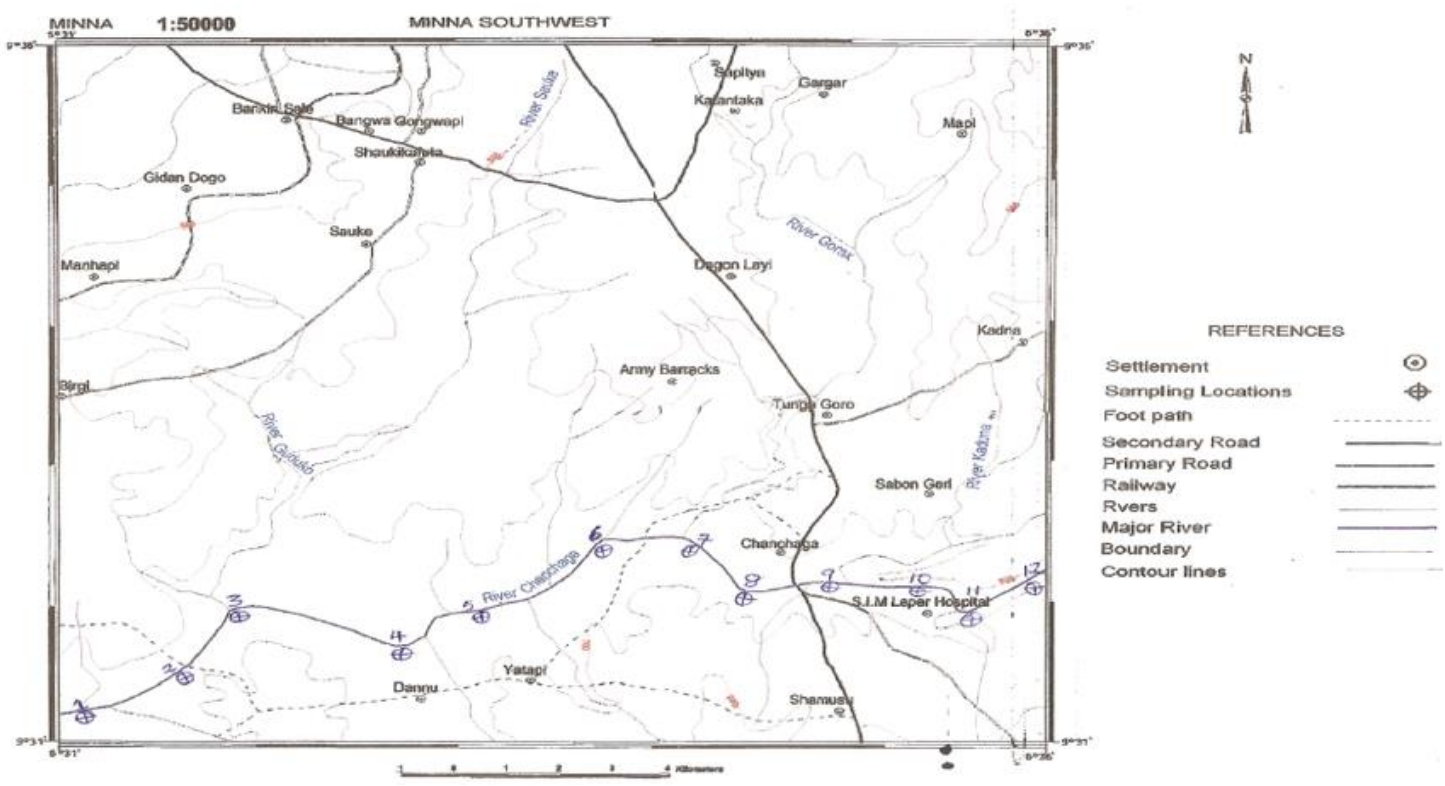

Figure 1: Topo-Map of Minna Niger State showing River Chanchaga with numbering 1-12

\subsection{Study Design}

The experiment was carried out under a Completely Randomized Design (CRD) with four samples and three replicate groups for each. The concentrations of the Heavy metals both in water and fish samples, were done in four groups, from group 1 to 4 , which are samples from Chanchaga river and a control pond (where no activities) using two species of fish. Both water and fish sample were randomly collected and analyzed for water physicochemical properties and Heavy metals $\mathrm{As}, \mathrm{Cd}, \mathrm{Cr}, \mathrm{Cu}, \mathrm{Hg}$ and $\mathrm{Pb}$.

\subsection{Sample Collection}

Sampling of Adult $O$. niloticus and C. gariepinus was carried out during February and June 2019 (dry and wet seasons respectively). Two experimental gill nets (measuring $30 \mathrm{~m}$ length, $1.5 \mathrm{~m}$ depth with stretch mesh size of 3 and 4 inches) were set up and left for three consecutive days. Each net was inspected every day for three days from morning until afternoon. The net was set up along the river that covers the most river pools. The total of 36fish of similar weights was used from the study area and Makolofish pond. The average lengthand weight of the samples were $38 \mathrm{~cm}$ and $1 \mathrm{~kg}$ from the river and fish farm. Water samples were also collected from the study samples and the control in plasticcontainers, sealed and transferred to thelaboratory in iced packs. Approximately $1 \mathrm{ml}$ of concentration $\mathrm{HNO}_{3}$ is added to the water samples to prevent the microbial utilization of heavy metals. The fish sampleswere frozen in the laboratory in a clean ice Box before heavy metal analysis.

\subsection{Fish Tissue Preparation}


Fish samples were rinsed with distilled water to get rid of any remnants of trace metals on the outersurface of the fish, and the scales were removed. Muscle tissues of fish (dorsal muscle) was used in this study because it is the major target tissue for metal storage and is the most edible part of the fish. Fish tissues were cut and oven dried for 3 hours at $110^{\circ} \mathrm{C}$ to a constant weight. After ensuring of samples dryness they wereremoved and then were grounded into powder using ceramic mortar and sieved through $20 \mu \mathrm{m}$ mesh and then stored in polyethylene bottles at $30^{\circ} \mathrm{C}$ until analysis. A wet digestion method was used based on the Analytical Methods for Atomic Absorption Spectrometry.

\subsection{Physico-chemical Properties}

\subsection{1 pH}

The $\mathrm{pH}$ value which is a measure of the hydrogen or hydroxyl ion activity of the water system indicates whether the water is acidic, neutral or alkaline in reaction. Fishes suffers much both under very low as well as high $\mathrm{pH}$. The instrument for $\mathrm{pH}$ measurement commonly used is a digital $\mathrm{pH}$ meters have single electrode assembly. The instrument being a potentiometer, the $\mathrm{pH}$ scale has to be calibrated before use with buffer solutions of known $\mathrm{pH}$ values. $75 \mathrm{ml}$ of water sample is taken in a $100 \mathrm{ml}$ beaker. The suspension is stirred at regular intervals for 30 minutes and the $\mathrm{pH}$ is recorded. The suspension is stirred well just before the electrode are immersed and readings are taken. Three readings were observed and then mean of it was calculated.

\subsubsection{Temperature}

Water temperature was determined using a mercury-in-glass thermometer.

\subsubsection{Dissolved Oxygen}

Dissolved oxygen (DO) was performed by Wrinkler method(Boyd, 1979). Manganous sulfate solution ( $2 \mathrm{ml}$ ) and $2 \mathrm{ml}$ of alkaline potassium iodide was added to the water. The solutions were mixed thoroughly. $2 \mathrm{ml}$ of conc. Sulfuric acid was added to it. From the above solution $200 \mathrm{ml}$ was transferred into a conical flask. Few drops of starch indicator were added. Then it was titrated against sodium thiosulfate till blue color turns violet. The amount of titrants used gives DO value. Three readings were taken and mean of it was calculated.

The oxygen content of the water was obtained by calculation using the formula:

D.O. content $(\mathrm{mg} / \mathrm{L})=$ Volume of original sample taken/Volume of sample titrated $\times \mathrm{A}$

Where $\mathrm{A}=$ Volume of the thiosulphate used in titration.

\subsubsection{Electrical Conductivity}

The electrical conductivity was determined by Richards, 1954. In this method, a $5 \mathrm{ml}$ of sample water mixture is shaken for 30 minutes, allowed to settle then the conductivity measured with a temperature-compensated probe. An approximate soluble salts value may be derived from the conductivity using the empirical relationship:

Soluble salts $(\%)=$ Conductivity $(\mathrm{dS} / \mathrm{m}) \times 0.35$. 
Vol. 4, No. 05; 2019

ISSN: $2456-8643$

\section{Digestion of Water Samples}

Water samples were analysedby a modified procedure from the Association ofOfficial Analytical Chemists (AOAC, 1995). Nitric acid $(10 \mathrm{ml})$ was added to $50 \mathrm{ml}$ of each water sample and heated at $150^{\circ} \mathrm{C}$ for $30 \mathrm{mins} .5 \mathrm{ml}$ of nitricacid was then added to each tube and heated for 30 minutes at $200 \mathrm{oC}$, to the mixture was added $2 \mathrm{ml}$ ofhydrogen peroxide before further heating at $200^{\circ} \mathrm{Cfor}$ 30minutes. The resulting solutions were allowedto cool at room temperature and then the volumemade up to $25 \mathrm{ml}$ with distilled water. Digested samples were analyzed for levels ofAs, $\mathrm{Cd}, \mathrm{Cr}, \mathrm{Cu}, \mathrm{Hg}$ and $\mathrm{Pb}$ using AtomicAbsorption Spectroscopy.

\subsection{Digestion of Fish Samples}

A $5 \mathrm{~g}$ of the dry powdered sample was put into a $50 \mathrm{ml}$ beaker with $5 \mathrm{ml}$ of $\mathrm{HNO}_{3}$ and $5 \mathrm{ml}$ of $\mathrm{H}_{2} \mathrm{SO}_{4}$. When the fish tissue stopped reacting with $\mathrm{HNO}_{3}$ and $\mathrm{H}_{2} \mathrm{SO}_{4}$, the beaker was then placed on a hot plate and heated at $60^{\circ} \mathrm{C}$ for $30 \mathrm{~min}$. After allowing the beaker to cool, $10 \mathrm{ml}$ of $\mathrm{HNO}_{3}$ was added and returned to the hot plate to be heated slowly to $120^{\circ} \mathrm{C}$. The temperature was increased to $150^{\circ} \mathrm{C}$, and the beaker was removed from the hot plate when the samples turned black. The sample was then allowed to cool before adding $\mathrm{H}_{2} \mathrm{O}_{2}$ until the sample was clear. The content of the beaker was transferred into a $50 \mathrm{ml}$ volumetric flask and diluted to the mark with ultra-pure water. All the steps were performed in the fume hood. Digested samples were analyzed for levels of As, $\mathrm{Cd}, \mathrm{Cr}, \mathrm{Cu}, \mathrm{Hg}$ and $\mathrm{Pb}$ using Atomic Absorption Spectroscopy. The above procedures in this section followed the guidelines from the Analytical Methods for Atomic Absorption Spectroscopy (Perkin Elmer 1996).

\subsection{Bioaccumulation factor (BAF)}

The ratio of the contaminant in the fish to the concentration in the ambient environment at a steady state, where the fish can take in the contaminant through ingestion with its food as well as through direct content (U.S. Environmental Protection Agency, 2010). The transfer coefficient was calculated by dividing the concentration of toxic metals in fish by the total toxic metals concentration in the water.This index of water - fish transfer or intake of toxic elements from water through fish was calculated using:

$\mathrm{BAF}=\mathrm{C}_{\mathrm{fish}} / \mathrm{C}_{\text {water }}$

Where;

BAF represent the transfer factor of snail

$\mathrm{C}_{\text {fish }}=$ Toxic elements concentration in fish tissue, $\mathrm{mg} / \mathrm{kg}$ fresh weight

$\mathrm{C}_{\text {water }}=$ Toxic elements concentration in water, $\mathrm{mg} / \mathrm{kg}$ dry weight

$\mathrm{BAF}>1$ indicates that the fish are en-riched in elements from the water (Bio-accumulation)

$\mathrm{BAF}<1$ means that the water excluded the toxic elements from water (excluder)

\subsection{Risk Assessment of Heavy Metals viathe Consumption of Fishes}

Risk assessment was evaluated by considering only theedible part (muscles tissues) to determine daily intake of metal (DIM), health risk index (HRI) and hazard index (HI).

\subsubsection{Daily Intake of Metals (DIM)}


The daily intake of metals (DIM) was calculated to estimatethe daily loading of metals into the body system (via theconsumption of fish meal) of a specified body weight of aconsumer according to (USEPA, 2011). This would entail the relative bioavailability of thestudied metals in this study. The daily intake of metals (DIM)was determined by the following:

$\mathrm{ADDM}=\mathrm{DI}(\mathrm{kg} / \mathrm{day}) \times \mathrm{M}_{\mathrm{fish}}(\mathrm{mg} / \mathrm{kg}) / \mathrm{BW}(\mathrm{kg})$

Where;

$\mathrm{ADDM}=$ Average daily dose $(\mathrm{mg}, \mathrm{kg} / \mathrm{d})$ of the metal into the body via the consumption of fish. $\mathrm{DI}=$ The daily intake of fish for adult is $0.227 \mathrm{~kg} / \mathrm{day}^{-1}$ for food describe by Shakeriet al., 2015 $\mathrm{M}_{\mathrm{fish}}=$ The trace toxic elements (metals) concentration in the fish tissues ( $\mathrm{mg} / \mathrm{kg}$ )

$\mathrm{BW}=$ Represent the estimated average body weight of investigated in adult (60kg for adults).

\subsubsection{Health Risk Index (HRI)}

The health risk index (HRI) for the populations through theconsumption of contaminated fish from sludge contaminated river was assessed based on thedaily intake of metals (DIM) relative to reference oral dose(RfD) for each metal. This is an index justifying individual'srisk of heavy metals. The HRI value of less than one impliessafe tread and is considered acceptable; otherwise, the fish may pose heavy metals risk. The following equation describe by USEPA, 2017 is used to calculate the HRI of fish.

\section{$\mathrm{HRI}=\mathrm{ADDM} / \mathrm{RfDM}$}

Where;

$\mathrm{ADDM}=$ represents the average daily dose $(\mathrm{mg}, \mathrm{kg} / \mathrm{d})$ of the metal

$\mathrm{RfDM}=$ is the reference dose of the metal $(\mathrm{mg}, \mathrm{kg} / \mathrm{d})$

RFDM is define as the maximum tolerable daily intake of metal with no adverse effect.

HRI is the ratio between exposure and the reference oral dose (RfD). If the ratio is lower than one (1), there will be no obvious risk.

\subsubsection{Estimation of Hazard Index (HI)}

The hazard index (HI) was calculated to determine the overall risk of exposure to all the heavy metals via the ingestion of a contaminated fish (USEPA, 2002). The hazard index (HI) was calculated as the summation of the hazard quotient (HQ) arising from all the metals examined. The value of the hazard index is proportional to the magnitude of the toxicity of the fish consumed. HI $>1$ indicates that the predicted exposure is likely to pose potential health risks. However, a hazard index $>1$ does not necessarily indicate that a potential adverse health effects will result, but only indicates a high probability of posing health risks.

$\mathrm{HI}=\Sigma \mathrm{HQAs}+\mathrm{HQCd}+\mathrm{HQCr}+\mathrm{HQCu}+\mathrm{HQHg}+\mathrm{HQPb}$

\subsection{Statistical Analysis}

The data obtained were analysed using IBM Statistical Product and Service Solution (SPSS) version 20 and Microsoft excel 2013. The results were expressed as mean \pm standard deviation (SD). One way analysis of variance (ANOVA) was carried out as $P<0.05$ considered statistically significant. 


\section{RESULTS}

\subsection{Physicochemical Properties of Chanchaga River and Makolo pond}

A number of physico-chemical properties (dissolved oxygen, $\mathrm{pH}$, Temperature, and electrical conductivity) of water in this study were determined shown in Table 1.The values of physicochemical properties of $\mathrm{C}$. river and $\mathrm{M}$. pond were dissolve oxygen(5.18 and 6.26 $\mathrm{mg} / \mathrm{l}), \mathrm{pH}(5.28$ and 6.55$)$, Temperature $\left(35.83\right.$ and $\left.28.10^{\circ} \mathrm{C}\right)$, and electrical conductivity (680.04 and $583.61 \mathrm{mg} / \mathrm{l})$ respectively which are significantly different $(\mathrm{P}<0.05)$. The physicochemical changes in water parameter may be due to the sludgedischarge and other anthropogenic activities.

Table 1: Physicochemical Properties of Chanchaga River and Makolo pond

\begin{tabular}{|llll|}
\hline Physicochemical & \multicolumn{2}{l}{ Water Samples } & \\
\cline { 2 - 3 } Properties & Chanchaga River & Makolo Pond & $\begin{array}{l}\text { WHO, 2004**, 2010* } \\
\text { Permissible Limit }\end{array}$ \\
\hline Dissolve Oxygen $(\mathrm{mg} / \mathrm{l})$ & $5.18 \pm 0.01$ & $6.26 \pm 0.02$ & $6-8 \mathrm{mg} / \mathrm{l}^{*}$ \\
$\mathrm{pH}$ & $5.28 \pm 0.02$ & $6.55 \pm 0.04$ & $6.5-8.5^{*}$ \\
Temperature $\left({ }^{\circ} \mathrm{C}\right)$ & $35.83 \pm 0.05$ & $28.10 \pm 0.49$ & $20-30^{\circ} \mathrm{C}^{*}$ \\
Electrical Conductivity $(\mathrm{mg} / \mathrm{l})$ & $680.04 \pm 5.65$ & $583.61 \pm 3.03$ & $500 \mathrm{mg} / \mathrm{l}^{* *}$ \\
\hline
\end{tabular}

Results Expressed as Mean \pm SD.

\subsection{Concentration of Heavy Metals in Water Samples}

The mean concentration of heavy metals ( $\mathrm{As}, \mathrm{Cd}, \mathrm{Cr}, \mathrm{Cu}, \mathrm{Hg}$ and $\mathrm{Pb}$ ) indifferent water samples (Chanchaga river and Makolo pond)were 2.18, 3.81,1.79, 2.24, 3.66, $2.86 \mathrm{mg} / \mathrm{kg}$, and 0.84, 0.92, $1.05,1.47,0.76,0.95 \mathrm{mg} / \mathrm{kg}$ respectively as shown in Table 2 . The result of C. river shows a significant different $(P<0.05)$ between the M. pond. The result shows that water samples from $\mathrm{C}$. river were more contaminated with Heavy metals compared to water from $\mathrm{M}$. pond.The concentration of $\mathrm{As}, \mathrm{Cd}, \mathrm{Cr}, \mathrm{Cu}, \mathrm{Hg}$ and Pbwere above the WHO/FAO, 2016 permissible limits of HMs in water $0.01,0.003,0.05,1.0,0.001$, and $0.01 \mathrm{mg} / \mathrm{kg}$ respectively. The study also indicates that $\mathrm{Cd}$ in the $\mathrm{C}$. river among the metals had the highest concentration, while $\mathrm{Cr}$ was the lowest.

Table 2: Concentration of Heavy Metals in Water Samples

\begin{tabular}{|llcl|}
\hline Heavy Metals & \multicolumn{2}{c|}{ Water Samples } & \\
\cline { 2 - 3 } & Chanchaga River & Makolo Pond & $\begin{array}{l}\text { PL(mg/kg) by FAO/ } \\
\text { WHO, 2016) }\end{array}$ \\
\hline As & $2.18 \pm 0.05$ & $0.84 \pm 0.09$ & 0.01 \\
Cd & $3.81 \pm 0.10$ & $0.92 \pm 0.04$ & 0.003 \\
\hline
\end{tabular}




\begin{tabular}{|llll|}
\hline $\mathrm{Cr}$ & $1.79 \pm 0.01$ & $1.05 \pm 0.04$ & 0.05 \\
$\mathrm{Cu}$ & $2.24 \pm 0.06$ & $1.47 \pm 0.10$ & 1.0 \\
$\mathrm{Hg}$ & $3.66 \pm 0.06$ & $0.76 \pm 0.07$ & 0.001 \\
$\mathrm{~Pb}$ & $0.95 \pm 0.04$ & 0.01 \\
\hline \multicolumn{2}{l}{ Results Expressed as Mean \pm SD. PL=Permissible limit, $\mathrm{n}=3$} \\
\hline
\end{tabular}

\subsection{Concentration of Heavy Metals in Fish Samples}

Table 3 presents the summary of the mean concentrations ( $\mathrm{mg} / \mathrm{kg}$ ) of heavy metals Arsenic (As), Cadmium $(\mathrm{Cd})$ Cromium $(\mathrm{Cr})$, Copper $(\mathrm{Cu})$,Mercury $(\mathrm{Hg})$ and Lead $(\mathrm{Pb})$ analysed in Oreochromisniloticus, and Clariasgariepinus from Chanchaga river and Makolo pond. The concentration of $\mathrm{HMs}(\mathrm{As}, \mathrm{Cd}, \mathrm{Cr}, \mathrm{Cu}, \mathrm{Hg}$, and $\mathrm{Pb})$ in $O$. niloticusand C. gariepinus from C.riverwere $2.66,3.72,1.84,2.23,3.68,2.88$ and $2.83,3.87,2.12,2.66,3.87,2.61 \mathrm{mg} / \mathrm{kg}$ also from Makolo pond were $0.69,0.98,1.04,0.83,0.54,1.00$ and 0.79, 0.98, 1.16, 1.02, 0.87, 1.16 $\mathrm{mg} / \mathrm{kg}$ respectively. The mean concentration of HMs in the fishes indicate bioaccumulation from the river.The result shows that fishes from C. riverwere more contaminated with HMs compared to the control from M. farm. The concentration of HMs on fish from $\mathrm{C}$. river were all greater than the maximum permissible limit of $\mathrm{HMs} \mathrm{As}, \mathrm{Cd}, \mathrm{Cr}, \mathrm{Cu}, \mathrm{Hg}$ and $\mathrm{Pb}$ in fish 0.01, 0.05, 1.5, 0.5, $0.01,0.3 \mathrm{mg} / \mathrm{kg}$ respectively recommended by FAO/WHO (2016);FAO, 1993 and Sahaet al., 2016. While the fishes from M. pond were also slightly greater than the maximum permissible limit except $\mathrm{Cr}$ which is below the recommended values. (Table 3).

\section{Table 3: Concentration of Heavy Metals in Fish Samples}

\begin{tabular}{|c|c|c|c|c|c|}
\hline \multirow{2}{*}{$\begin{array}{l}\text { Heavy } \\
\text { Metals } \\
(\mathrm{mg} / \mathrm{kg})\end{array}$} & \multicolumn{4}{|l|}{ Fish Samples } & \multirow[b]{2}{*}{$\begin{array}{l}\mathrm{PL}(\mathrm{mg} / \mathrm{kg}) \text { by } \\
\text { FAO/WHO, } \\
2016^{*} \text {, Saha et } \\
\text { al., } 2016^{* *}\end{array}$} \\
\hline & $\mathrm{CO}$ & $\mathrm{CC}$ & MO & $\mathrm{MC}$ & \\
\hline As & $2.66 \pm 0.06^{\mathrm{b}}$ & $2.83 \pm 0.06^{\mathrm{a}}$ & $0.69 \pm 0.06^{c}$ & $0.79 \pm 0.03^{c}$ & $0.01 *$ \\
\hline $\mathrm{Cd}$ & $3.72 \pm 0.04^{b}$ & $3.87 \pm 0.10^{\mathrm{a}}$ & $0.98 \pm 0.02^{\mathrm{c}}$ & $0.98 \pm 0.02^{\mathrm{c}}$ & $0.05^{*}$ \\
\hline $\mathrm{Cr}$ & $1.84 \pm 0.05^{b}$ & $2.12 \pm 0.02^{\mathrm{a}}$ & $1.04 \pm 0.01^{\mathrm{d}}$ & $1.16 \pm 0.01^{\mathrm{c}}$ & $1.5^{* *}$ \\
\hline $\mathrm{Cu}$ & $2.23 \pm 0.02^{\mathrm{b}}$ & $2.66 \pm 0.07^{\mathrm{a}}$ & $0.83 \pm 0.09^{\mathrm{d}}$ & $1.02 \pm 0.03^{\mathrm{c}}$ & $0.5^{*}$ \\
\hline $\mathrm{Hg}$ & $3.68 \pm 0.02^{\mathrm{b}}$ & $3.87 \pm 0.09^{\mathrm{a}}$ & $0.54 \pm 0.13^{\mathrm{d}}$ & $0.87 \pm 0.10^{\mathrm{c}}$ & $0.01 *$ \\
\hline $\mathrm{Pb}$ & $2.88 \pm 0.03^{\mathrm{a}}$ & $2.61 \pm 0.04^{b}$ & $1.00 \pm 0.01^{\mathrm{d}}$ & $1.16 \pm 0.01^{\mathrm{c}}$ & $0.3^{*}$ \\
\hline
\end{tabular}




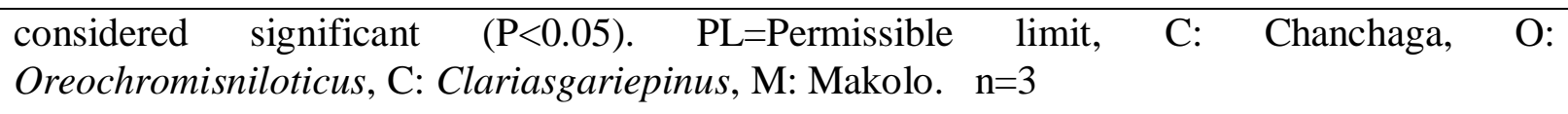

\subsection{Estimation of bioaccumulation factor (BAF) of Toxic Element in fishes}

The bioaccumulation factor (BAF) of HMs from the test river to fishes, which gives the ratio of the concentration of HMs in fish to the total concentration in the water. The BAF also shows the amount of elements that is transferred from water to fish. The BAF of metals $\mathrm{As}, \mathrm{Cd}, \mathrm{Cr}, \mathrm{Cu}, \mathrm{Hg}$, and $\mathrm{Pb}$ obtained in fish (O. niloticus, and C.gariepinus) from C. river were 1.22, 0.97, 1.02, 0.99, $1.00,1.00$, and 1.29, 1.01, 1.18, 1.18, 1.05, 0.91. Fishes from M. pond were 0.82, 1.06, 0.99, $0.56,0.71,1.05$ and $0.94,1.06,1.10,0.69,114,1.22$ respectively. Where the BAF is greater than one $(>1)$ indicates that the fishes are enriched with the elements from the water (Bioaccumulators). Also where BAF is less than one $(<1)$ means that the fishesexclude the elements from the water (excluders). In this study the BAF shows that Cat fish C.gariepinus bio accumulate more HMs in both C. river and M.pond compared to Tilapia fish O. niloticus which shows that different species of fish have different rate of accumulation(Fig. 1).

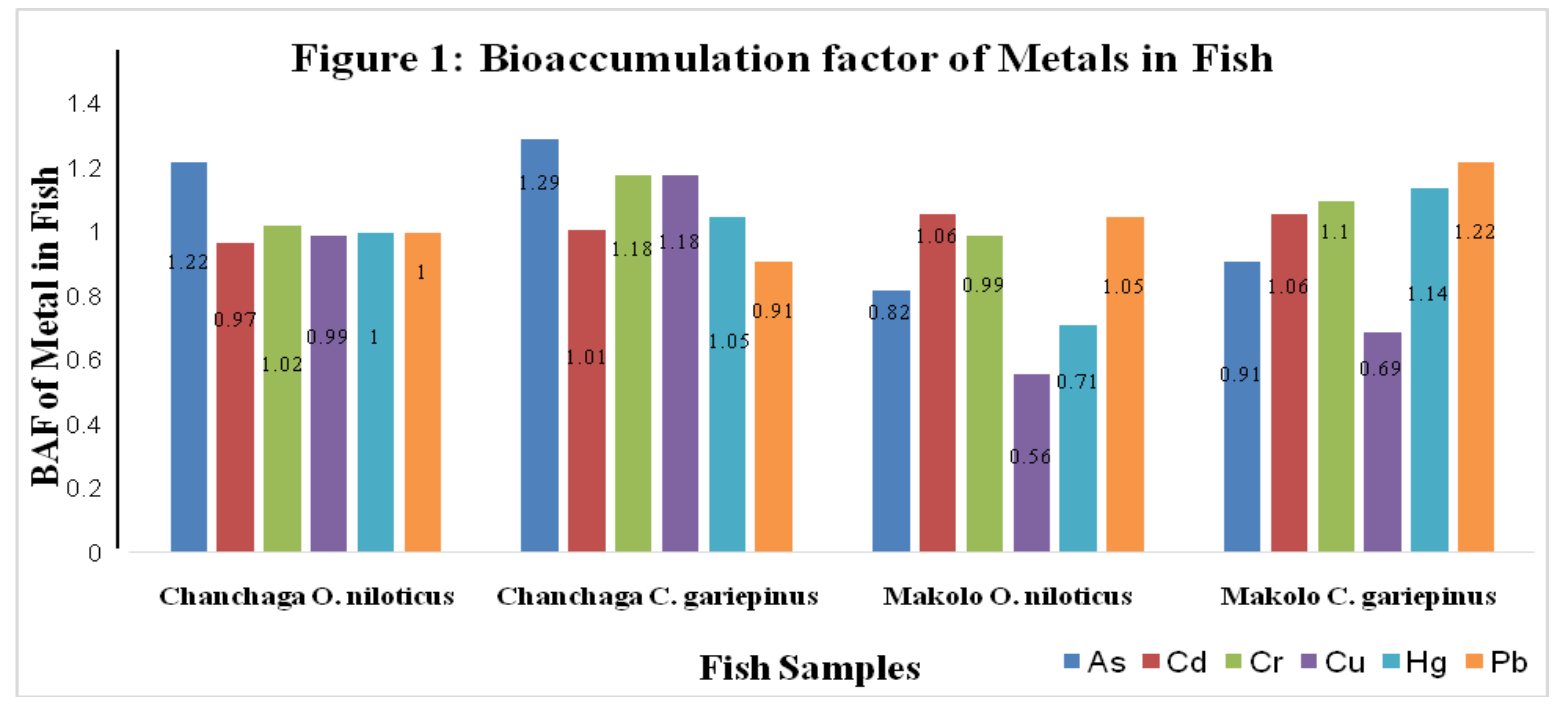

\subsection{Estimation of average daily dose of metal (ADDM) for adult}

The average daily dose of into the body system for adult (via the consumption of fish meal)was estimated according to the average fish consume through the food chain. The ADDM values for HMs (As, $\mathrm{Cd}, \mathrm{Cr}, \mathrm{Cu}, \mathrm{Hg}$, and $\mathrm{Pb}$ ) inO. niloticus, and C.gariepinus from C. river were 0.010, 0.014, 0.007, 0.008, 0.014, 0.011 and 0.011, 0.015, 0.008, 0.010, 0.015, 0.010 and O. niloticus, and C.gariepinus from M. pond were 0.003, 0.003, 0.004, 0.003, 0.002, 0.004 and 0.003, 0.004, $0.004,0.004,0.003,0.004$ respectively for HMs. The result shows that fishes in C. river has higher values of ADDM compared to fish in M.pond (Fig. 2). 


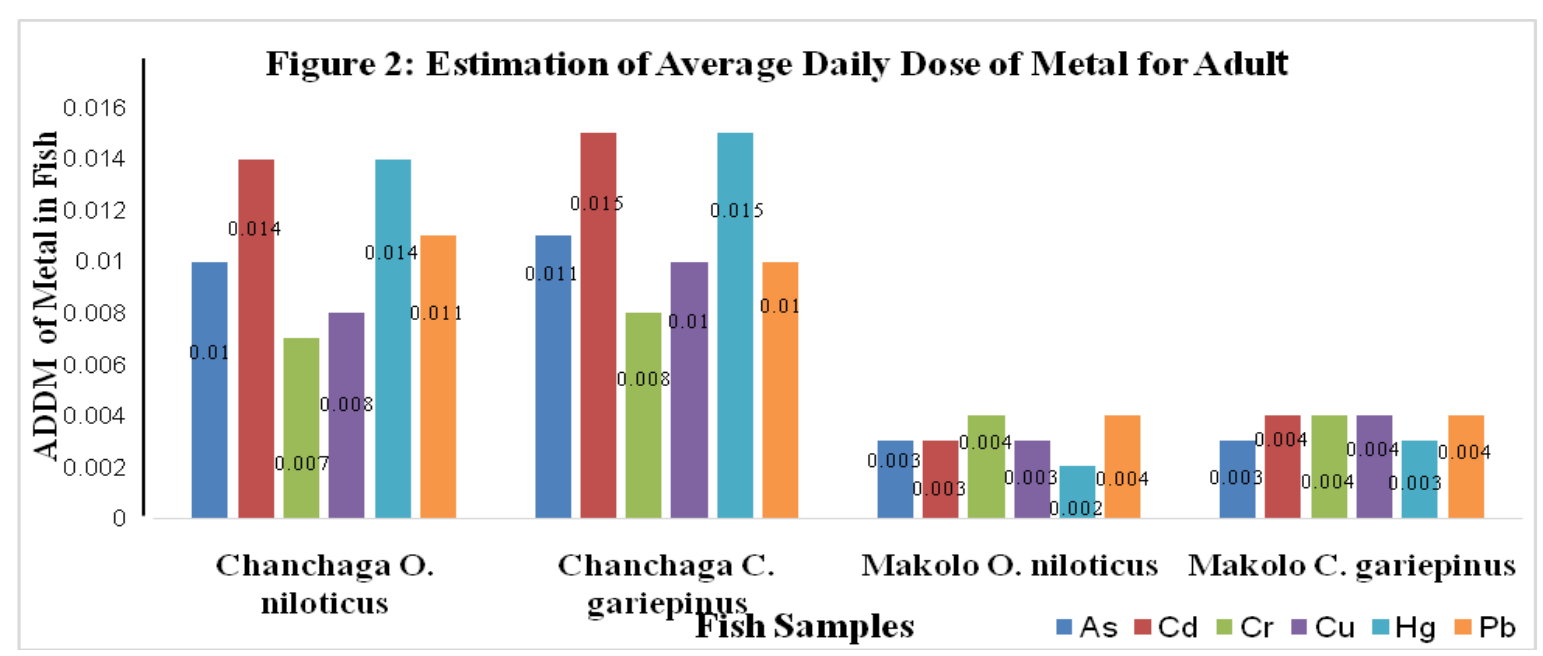

\subsection{Estimation of Health Risk Index HRI}

The HRI of metals through consumption of fish from C. river and M. pond were given in Fig.3. The HRI of $\mathrm{HMs} \mathrm{As}, \mathrm{Cd}, \mathrm{Cr}, \mathrm{Cu}, \mathrm{Hg}$, and $\mathrm{Pb}$ in O. niloticus, and C.gariepinus from $\mathrm{C}$. river were 1.00, 0.28, 0.00, 0.016, 1.40, 0.03 and 1.10, 0.30, 0.01, 0.02, 1.5, 0.03. Fishes from M.pond were $0.30,0.06,0.00,0.01,0.20,0.01$ and $0.30,0.08,0.00,0.01,0.30,0.01$ respectively for HMs.The HRI for fishes from C. river recorded high HRI than that of fishes from M. pond. Metals $\mathrm{As}$ and $\mathrm{Pb}$ from C.river were greater than one, which indicate toxicity (Fig. 3).

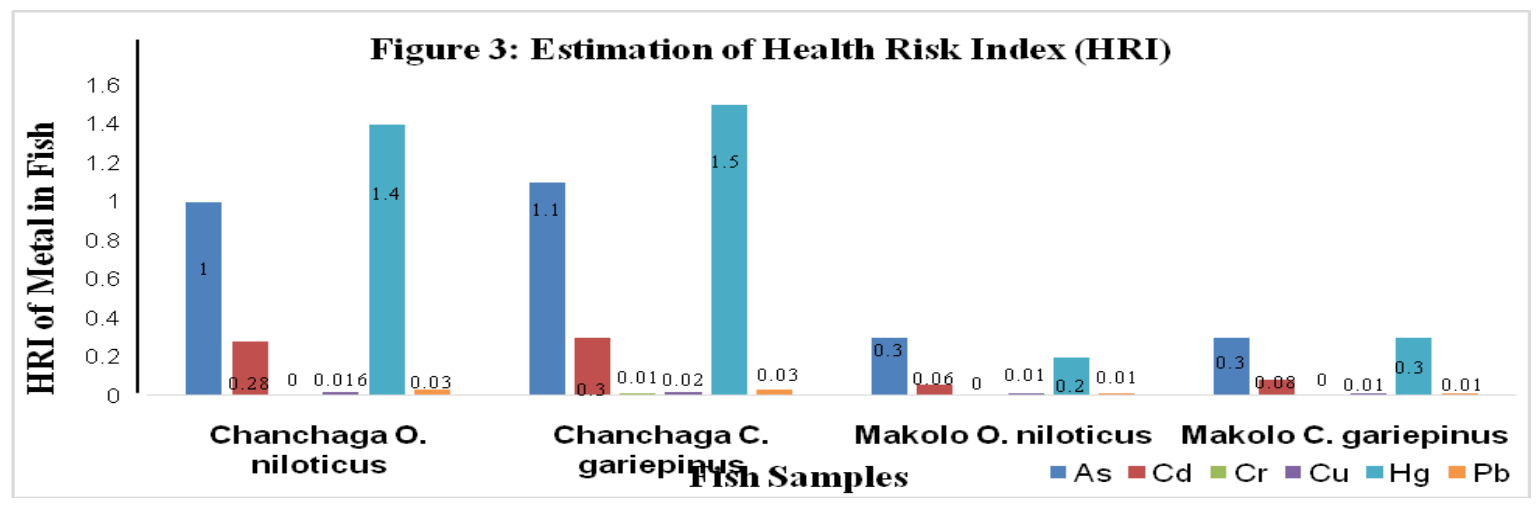

\subsection{Estimation of Hazard index (HI)}

The overall risk of exposure to all the heavy metals via the ingestion of a contaminated fish is shown in Fig.4. the total Index of all metals in O. niloticus, and C.gariepinus from C. river were 2.73 and 2.96 respectively and M.pond were 0.58 and 0.70 respectively. The result shows that Fishes from C.river were highly contaminated with heavy metals compare to the fish in M. pond. $\mathrm{HI}>1$ indicates that the predicted exposure is likely to pose potential health risks. 


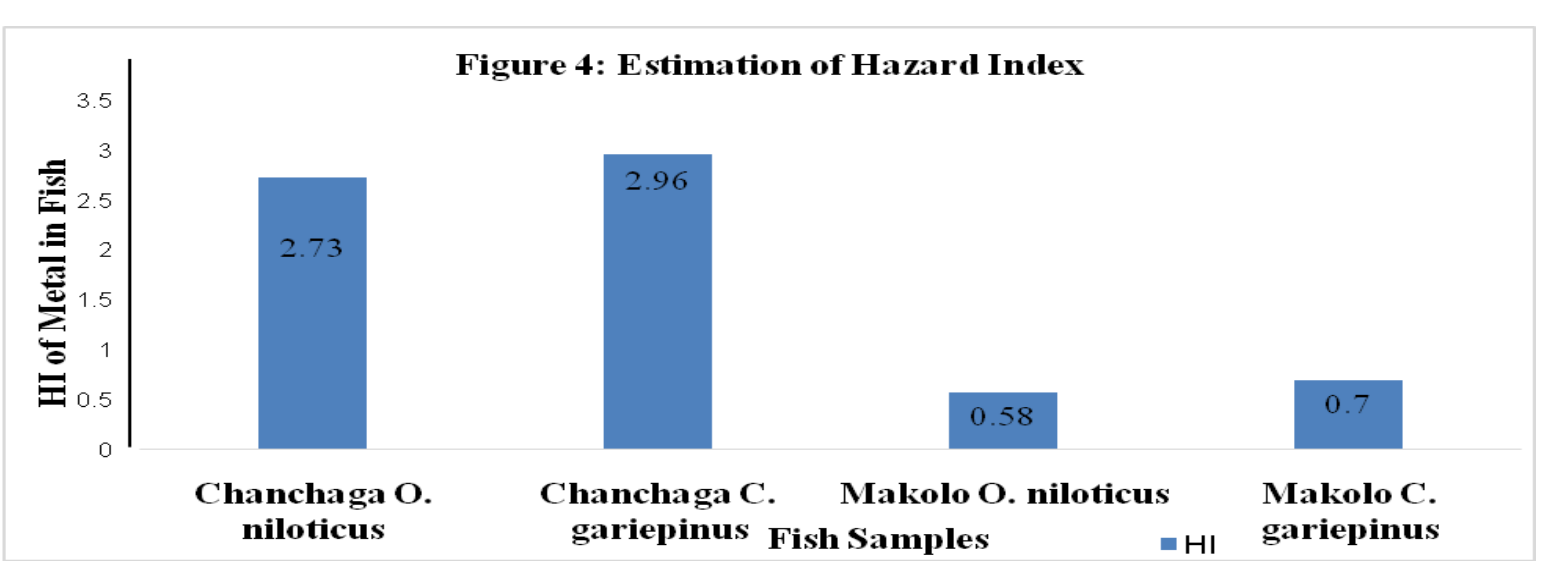

\section{DISCUSSION}

The physicochemical properties (Dissolve oxygen, $\mathrm{pH}$, Temperature, Electrical Conductivity) of water from C. river and M. pond were measured.The amount of dissolve oxygen in water has a major impact on fish behavior and survival. Dissolved oxygen (DO) refers to the level of free, non-bonded oxygen present in water. Chanchagariver has lower DO with $5.18 \mathrm{mg} / \mathrm{l}$ compared to Makolo fish pond water with $6.26 \mathrm{mg} / \mathrm{l}$.the lower DO in C.river can lead to hypoxia. The recommended minimum dissolved oxygen require in fresh water is within $6-8 \mathrm{mg} / \mathrm{l}$. the lower DO in C.river may be due to the waste discharge in the river which covers the surface of the river for oxygen penetration. The oxygen dissolves by diffusion from the surrounding air. Oxygen level can be reduced depending on pollutants present, dissolved minerals such as salt and temperature.Most fish species tolerate a drop below these minimum values for a short period of time and the period of time during which the oxygen levels drops below required limit, will cause fish to become stressed. The lower the concentration of DO, the greater the stress. The stress can cause fish death. C.river recorded low pH concentration than M.pond (5.28 and 6.55) respectively. Low $\mathrm{pH}$ level reduces the active nature of fish and also accelerate the release of heavy metals which is due to the waste water channel to the river and also runoff from polluted environment. TheWorldHealthOrganization(WHO,2010)recommendsapHvalueof6.5 8.5 fordrinkingwatertopreventcorrosion. Fish are influenced by the temperature around them because they are unable to regulate their body temperature. River Chanchaga recorded higher temperature and electrical conductivity (35.83 and 680.04) than Makolo fish pond (28.10 and 583.61).High temperature do not hold enough oxygen for aquatic organisms to survive. Increase in water temperature means a decrease in dissolved oxygen available for the fish to breathe from the water.Watertemperatureaccording(Lenntech,2014)affectstheECsothatitsvalueincrease sfrom 2 upto3\% per $1{ }^{\circ} \mathrm{C}$. The average limit of temperature in fish water is $20-30{ }^{\circ} \mathrm{C}$. The increase in EC may be due to runoff, sewage waste, sludge, which also increases chloride, phosphate, and nitrate ions. Lower $\mathrm{pH}$ also increase electrical conductivity. The permissible limit of $\mathrm{EC}$ is $500 \mathrm{mg} / \mathrm{l}$. 
The result of Chanchaga river shows a significant different $(P<0.05)$ between Makolo pond. The result shows that water samples from C. river were more contaminated with Heavy metals compared to water from makolo farm. The sequence of occurance for C.riverCr $<\mathrm{As}<\mathrm{Cu}<\mathrm{Pb}<\mathrm{Hg}<\mathrm{Cd}$ and for $\mathrm{M}$.pond $\mathrm{Hg}<\mathrm{As}<\mathrm{Cd}<\mathrm{Pb}<\mathrm{Cr}<\mathrm{Cu}$.Lead and cadmium levels were significantly higher in water samples from C. river than in the M.pond control samples. This is probabalyas a result of heavy metals from water treatment plant sludge discharge in the water, which are main pollutants in Chanchaga River. The heavy metal concentrations recorded in C. river were higher than standard limits for portable water and aquaculture (FAO/WHO, 2016).Aquatic life abound in the waters and can bioaccumulate these metals andsubsequently transfer it to consumers via foodchain.

Fish being at the higher level of the food chain accumulate large quantities of metals and the accumulation depends upon the intake and elimination from the body. There was a highly significant difference in the concentrations of HMs in fish's species (O.niloticus and C.gariepinus) from C.river and M. river.There was a significant increase of metal in C.gariepinus than in O. niloticus from C.river. The variation in the level of heavymetal accumulation in different fish species may support the view that thereis a variation in ability of different fish to accumulate heavy metals. The present of scales in $O$. niloticus also reduces the transfer of metals. The entire fishSamplesfrom C. river and M. pond contained detectable levels of the elements studied. The accumulation of these heavy metals in fish may represent a health risk, especially for populations with high consumption rates of fish (Oguh et al., 2019c). Oneway Analysis of variance (ANOVA) revealed a significant $(\mathrm{P}<0.05)$ variation in the concentrations of HMs in C.river and M.pond, which is an indication of the extent of metal pollution from the river. Generally Chanchaga river had higher heavy metals concentrations (As, $\mathrm{Cd}, \mathrm{Cr}, \mathrm{Cu}, \mathrm{Hg}$, and $\mathrm{Pb}$ ) than the controls, which were all above the FAO/WHO, 2016 permissible limit of $0.01,0.05,1.5,0.5,0.01$, and $0.3 \mathrm{mg} / \mathrm{kg}$ respectively (Table 3 ). The mean values recorded at the control pond were also higher than the FAO/WHO acceptable value except $\mathrm{Cr}$ which is below the permissible limit of $1.5 \mathrm{mg} / \mathrm{kg}$. The mean concentration of heavy meals in O.niloticus and C.gariepinus from C.river is decrease in the following order $\mathrm{Cd}>\mathrm{Hg}>\mathrm{Pb}>\mathrm{As}>\mathrm{Cu}>\mathrm{Cr}$. The levels of chromium were comparatively lower in the fish samples which is in accordance with the findings of joy et al., 2012. Heavy metals and nutrients absorbed by fish are usually translocated to different parts of the fish which could limit the concentrations in the river. However, availability of heavy metals in the water and continuous stay in the polluted water could lead to higher concentration in the fish.

The high concentration of As and $\mathrm{Cd}$ at C.river may be due to sludge from water treatment plant, atmospheric deposition, anthropogenic activities, combustion, etc. which translocated through the fishes. Arsenic affects almost all organs during its acute or chronic exposure. Liver has been reported as target organ of arsenic toxicity. Toxicity is due to arsenic's effect on many cell enzymes, which affect metabolism, DNA repair and brain problem. The most prominent chronic manifestations of As involve the skin, lungs, liver and blood systems. The levels of Cd recorded in this study was however much higher than thevalues of $0.27 \mathrm{mg} / \mathrm{kg}$ reported for fish by Hossam et al., 2017. Cadmium is a dangerous element because it can be absorbed via the alimentary track; penetrate through placenta during pregnancy and damage membrane and DNA. 
Vol. 4, No. 05; 2019

ISSN: $2456-8643$

Significant concentration of $\mathrm{Cd}$ may have gastrointestinal effect and reproductive effect onlivestock (Maobaet al., 2012). Ndukwuet al., 2008 reported that cadmium causesboth acute and chronic poisoning, adverse effecton kidney, liver, vascular and the immunesystem.

High dose of chromium is observed to cause Bronchopneumonia, chronic bronchitis, diarrhea, emphysema, headache, irritation of the skin, itching of respiratory tract, liver diseases, lung cancer, nausea, renal failure, reproductive toxicity, and vomiting. Copper is indeed essential, but in high doses it can cause anaemia, diarrhea, headache, metabolic disorders, nausea, vomiting, liver and kidney damage, stomach and intestinal irritation on human health. The levels of $\mathrm{Cu}$ recorded in this study was however much higher than the values of $0.02 \pm 0.002 \mathrm{mg} / \mathrm{kg}$ reported forC. anguillarisbyHanyet al., 2012. According to Maobaet al., 2012) high levels ofcopper can cause metal fumes fever with flu-like symptoms, hair and skin decolouration, dermatitis, irritation of the upper respiratory tract, metallic taste in the mouth and nose.

Mercury poisoning symptoms include blindness, deafness, brain damage, digestive problems, kidney damage, lack of coordination and mental retardation. The ability of fishes to accumulate essential metals equally enables them to acquire other nonessential metals from the river or pond. Lead has no beneficial biological function and is known to accumulate in the body. Basapor and Ngabaza, 2015 reported that lead causes both acute and chronic poisoning and thus, poses adverse effects on kidney, liver, vascular and immune system. Lead can cause serious injury to the brain, nervous system, redblood cells, low IQ, impaired development, shortened attention span, hyperactivity, mental deterioration, decreased reaction time, loss of memory, reduced fertility, renal system damage, nausea, insomnia, anorexia, and weakness of the joints when exposed to high lead. The bio-accumulated metals on the fish may interact directly with biomolecules such as nucleic acid, protein, carbohydrate, disrupting critical biological processes, resulting in toxicity and the concomitant transfer of these metals through the food chain could ultimately pose risk to human life (Huang et al., 2017; Oguh et al., 2019b).

The BAF of HMs from water-fish is the key component of human exposure to HMs through the food chain. The BAF of O.niloticus and C.gariepinus from C. riverwere significantly different from M.pond. This indicate the high presence of metals in the C. river. The more the presence of metal in the water the more the bioaccumulation on the fish. The water-fishBAF of O.niloticus from C.river for $\mathrm{Cd}$ and $\mathrm{Cu}$, were below one $(<1)$ except $\mathrm{As}, \mathrm{Cr}, \mathrm{Hg}$, and Pbwhich were up to and greater than one (>1). The BAF of C.gariepinus from C.river for $\mathrm{As}, \mathrm{Cd}, \mathrm{Cr}$, and $\mathrm{Hg}$ were above one except $\mathrm{Pb}$ which is below one. The BAF of O.niloticus from M.pond were all below one except $\mathrm{Cr}$ and $\mathrm{Pb}$ while the BAF of $\mathrm{C}$.gariepinus were above one except $\mathrm{Hg}$ and As which were below $(<1)$. The BAF values below one $(<1)$ indicate that the fish do not take up toxic element or exclude the element from the river or pond shown in Fig. 1. Where BAF $>1$ indicates that the fish are en-riched in elements from the water(Bio-accumulation).

As intake of fish is a possible source of metal accumulation in humans, there is an important interest in calculation of the daily and weekly consumptions of heavy metals through fish eating. The ADDM values for heavy metals were significantly little high in fishes from C.river than fishes from M.pond. The highestintakes of $\mathrm{As}, \mathrm{Cd}, \mathrm{Cr}, \mathrm{Cu}, \mathrm{Hg}$, and $\mathrm{Pb}$ in fish were from C.river. 
The Daily intake indicate the amount of HMs that will be taken in the body when such fish is consume.

The HRI values forHeavy metals were significantly high in fishes from C.river. The (HRI) values weresignificantly $<1$; in fishes from M.pond; indicating that consumers offishes from these pond are not exposedhealth risk of $\mathrm{As}, \mathrm{Cd}, \mathrm{Cr}, \mathrm{Cu}, \mathrm{Hg}$, and $\mathrm{Pb}$. TheHMs As and $\mathrm{Hg}$ were greater than one $>1$ Which indicate thatconsumption of fishes from C. river will lead to accumulation of As and $\mathrm{Hg}$ in the body, which can lead to severe health problem.Hazard index (HI) shows the overall risk ofexposure to all the metal in fish from C. river and M.pond. The control fishes from M.pond were below $<1$; which indicates that the consumption of fish cannot pose health risk to consumer. The values of $\mathrm{HI}$ in fishes from C.riverwere above $>1$; it indicate that the consumption of all the fish can pose healthrisk to consumer through the intake of metal.

\section{CONCLUSION}

The present study concludes that heavy metals concentrations exceed the safe recommended value, which suggest that Chanchagariver is partly a heavy metal polluted river and the water, and fish are not fully safe for human health and ecosystem. The result also shows that Clariasgariepinus accumulate more heavy metals on fish tissue than Oreochromisniloticus. The community needs to be informed about the risk in consumption of these fishes.

\section{ETHICAL APPROVAL}

As per university standard guideline ethical approval has been collected and preserved by the authors.

\section{COMPETING INTERESTS}

Authors have declared that no competing interests exist.

\section{REFERENCES}

Al-Yousuf, M.H., El-Shahawi, M.S., Al-Ghais, S.M. (2000) Trace metals in liver, skin and muscle of Lethrinuslentjanfish species in relation to body length and sex. Sci Total Environ 256: 87-94.

Amundsen, P.A., Staldvik, F.J., Lukin, A.A., Kashulin, N.A, Popova, O.A. andReshetnikov, Y.S. (1997).Heavy metal contamination in freshwater fish from the border region between Norway and Russia. Sci. Total. Environ. 201:211-224.

Association of Official Analytical Chemist (AOAC), 1995: Official methods of Analysis, $15^{\text {th }}$ edition, Washington.

Authman, M.M.N. (2008) Oreochromisniloticusas a biomonitor of heavy metal pollution with emphasis on potential risk and relation to some biological aspects. Global Vet., 2(3): 104-109.

Authman, M.M.N., Zaki, M.S., Khallaf, E.A. and Abbas, H.H. (2015). Use of Fish as Bioindicator of the Effects of Heavy Metals Pollution. J Aquac Res Development 6: 328. doi:10.4172/2155-9546.1000328. 
Barka, S., Pavillon, J.F. andAmiard, J.C. (2001). Influence of different essential and nonessential metals on MTLP levels in the Copepod Tigriopusbrevicornis Comparative Biochemistry and Physiology Part C: Toxicol. Pharmacol. 128:479-493.

Basapor, N and Ngabaza, T. (2015). Toxicological effect of chlorpyrifis and lead on the acquatic snail Helisomaduryi. Advances in Biological Chemistry, 5:225-233.

Beijer, K and Jernelov, A. (1986). Sources, transport and transformation of metals in the environment. Handbook on the toxicology of metals. Elsevier, Amsterdam. pp, 68-84.

Boyd, C.E. (1979).Water Quality in warm Water Fish Ponds. Auburn University, Auburn.

Clarkson, T.W., L. Magos and G.J.J. Myers, 2003. The toxicology of mercury: Current exposures and clinical manifestations. New England Journal of Medicine, 349: 1731-1737.

Corpas, I., Bentio, M.J., Marquina, D., Castillo, M., Lopez N. and Antonio, M.T.(2002). Gestational and lactational lead intoxication produces alterations in the hepatic system of rat pups. Ecotoxicology and Environmental Safety, 51(1): 35-43.

Deore, S.V. and S.B. Wagh.(2012). Heavy metal induced histopathological alterations in liver of Channagachua(Ham). Journal of Experimental Science, 3(3): 35-38.

Food and agriculture organization of the united nation. (1993).Water quality and fish health, by Z. Svobodová, R. Lloyd, J. Máchová and B. Vykusová.EIFAC Technical paper 54. M.45 ISBN 92.5-103437.0

Hany, M. Y and Elwoa, S.S. (2012).Bioaccumulation of heavy metals in water, sediment and fish (Oreochromisniloticusand Clariasanguillaris), in Rosetta branch of the River Nile, Egypt.African Journal of Biotechnology, 11(77): 14204-14216.

Hassaan, M. A., El Nemr, A. and Madkour, F. F. (2016). Application of Ozonation and UV assisted Ozonation on Decolorization of Direct Yellow 50 in Sea water, The Pharmaceutical and Chemical Journal, 3(2): 131-138.

Hossam, A.Z., Adnan, M. A. and Hisham, N. W. (2017).Baseline Concentration of Heavy Metals in Fish Collected from Gaza Fishing Harbor in the Mediterranean Sea along Gaza Coast, Palestine. Turkish Journal of Fisheries and Aquatic Sciences 17: 101-109.DOI: 10.4194/13032712-v17_1_12.

Huang,Z, Lu, Q, Wang, J, Chen, X, Mao X, et al. (2017). Inhibition of the bioavailability of heavy metals in sewage sludge biochar by adding two stabilizers, 12 .

Jitar, O, Teodosiu, C, Oros A, Plavan G, Nicoara, M. (2014) Bioaccumulation of heavy metals in marine organisms from the Romanian sector of the Black Sea. N. Biotechnol. doi: 10.1016/j.nbt.2014.11.004. 
Joy, F.A.,Chiaka, I.A. and Henrietta O. A. (2013). Assessment of heavy metal residues in water, fish tissue and human blood from Ubeji, Warri, Delta State, Nigeria. J. Appl. Sci. Environ. Manag, 17(2) 291-297.

Kalay, M, Ay, O. andCanli, M. (1999). Heavy metal concentrations infish tissues from the Northeast Mediterrenean Sea. Bull. Environ.Contam. Toxicol. 63: 673-681.

Lars, J., 2003. Hazards of heavy metal contamination. British Medical Bulletin, 68(1): 167-182.

Lenntech,B.V.,2014.Watertreatmentsolutions.Delft,TheNetherlands.

Mahboob, S., Al-Balawi, H.F.A., Al-Misned, F., Al-Quraishy, S. and Ahmad, Z. (2014). Tissue metal distribution and risk assessment for important fish species from Saudi Arabia. Bull Environ ContamToxicol92: 61-66.

Mahino, F. and U. Nazura, 2013. Histopathology and Bioaccumulation of heavy metals ( $\mathrm{Cr}, \mathrm{Ni}$ and $\mathrm{Pb}$ ) in fish (Channastriatusand Heteropneustesfossilis) tissue: A study for toxicity and Ecological impact. Pakistan Journal of Biological Science, 16: 412-420.

Mansour, S.A.and Sidky M.M. (2002). Ecotoxicological Studies, 3 Heavy metals contaminating water and fish from Fayoum Governorate. Egypt J Food Chem. 78(1), 15-22.

Maobe, M.A.G., Gatebe, E., Gitu, L. and Rotich, H. (2012). Profile of heavy metals in selected medicinal plants used for the treatment of diabetes, malaria and pneumonia in Kisiiregion, Southwest Kenya. Global J. of Pharmacology, 6(3):245-251.

Marcus, A.C., Okoye C.O., Ibeto C.N. (2013). Bioaccumulation of trace metals in shellfish and fish of Bonny River and creeks around Okrika in Rivers State, Nigeria - Bull. Environ. Contam. Toxicol.90: 708-713.

Mohamed, A., Hassaan, A.E. and Fedekar, F.M. (2016). Environmental Assessment of Heavy Metal Pollution and Human Health Risk. American Journal of Water Science and Engineering. Vol. 2, No. 3, 2016, pp. 14-19. doi: 10.11648/j.ajwse.20160203.11.

Ndukwu, B.C., Obute, G.C. and Eze, E. (2008). Uptake and accumulation of heavy metals by plants on abandoned refuse dumpsites in parts of Rivers State, Nigeria. Scientia Africana,7:130140.

Oguh, C.E., Ubani, C.S., Osuji, C.A. andUgwu, V.C. (2019c). Heavy metal risk Assessment on the Consumption of Edible Vegetable TalinumTriangulare Grown on Sewage Dump Site in University of Nigeria, Nsukka. Journal of Research in Environmental Science and Toxicology.8(2): 104-112. DOI: http://dx.doi.org/10.14303/jrest.2019.034.

Oguh, C.E., Ugwu, C.V., Uzoefuna, C.C., Usman, S., Nkwocha, C.C. and Amanabo M. (2019b). Toxicity Impact on Bioaccumulation of Potentially Toxic Elements in African Giant Land Snail (Archachatinamargenata) treated with different soils and Its Ecological Risk Assessment. Asian 


$\begin{array}{lrrrrr}\text { Journal of } & \text { Research } & \text { in } & \text { Biochemistry, } & \mathbf{4}(4): & 1-15 . \\ \text { DOI:http://dx.doi.org/10.9734/AJRB/2019/v4i430077. } & & & \end{array}$

Oguh, C.E.,Uzoefuna, C.C., Oniwon, W.O., Ugwu, C.V., Ahaiwe, P.T., Okeke, C.B. and Ezikanyi, G.K. (2019a).Risk assessment on bioaccumulation of potentially toxic elements on soil and edible vegetables Corchorusolitorius and Amaranthuscruentus grown with water treatment sludge in ChanchagaMinna, Niger State, Nigeria. Journal of Research in Environmental Science and Toxicology,8(2): 92-103. DOI:http://dx.doi.org/10.14303/jrest.2019.033.

Olaifa, F.E., Olaifa A.K., Adelaja, A.A1, Owolabi, A.G. (2004). Heavy Metal Contamination OfClariasgariepinusFrom A Lake And Fish Farm In Ibadan, Nigeria.African Journal of Biomedical Research, Vol. 7: 145 - 148.

Perkin Elmer. (1996). Analytical methods for atomic absorption spectroscopy. USA: The PerkinElmer Corporation.

Richards, L.A. 1954. Diagnosis and Improvement of Saline and Alkali Soils. U.S. Salinity Laboratory, U.S. Dept. Agric. Hbk. 60, pp. 160.

Saha, N., Mollah, M., Alam, M. and Rahman, M. S. (2016).Seasonal investigation of heavy metals in marine fishes captured from the bay of Bengal and the implications for human health risk assessment. Food Control, 70, 110-118.

Sehar, A., Shafaqat, A., Uzma, S.A., Mujahid, F., Saima, A.B., Fakhir, H. and Rehan, A. (2014). Effect of Different Heavy Metal Pollution on Fish. Research Journal of Chemical and Environmental Sciences, 2(1): 74-79.

Selda, O.T. and Nurşah, A. (2012). Relationship of Heavy Metals in Water, Sediment and Tissue with Total Length, Weight and Seasons of Cyprinuscarpio L., 1758 From Isikli Lake (Turkey), Pakistan J. Zool, 44(5), 1405-1416.

Shakeri, A., Shakeri, R. andMehrabi, B. (2015). Potentially toxic elements and persistent organic pollutants in water and fish at ShahidRajaei dam, north of Iran.International journal of Environmental Science and Technology, 12(7), 2201-2212. https://doi.org/10.1007/s13762-0150754-9.

Stoeppler, M., 1991. Cadmium. In: Metals and Their Compounds in the Environment. (Ed. E. Merian) VCH publisher, Weinheim, Germany.

Toth, J.F. and Brown R.B. (1997). Racial and gender meanings of why people participate in recreational fishing. Leisure Sci. 19:129-146.

U.S. Environmental Protection Agency (2010). Bioaccumulation testing and interpretation for the purpose of sediment quality assessment: U.S. Environmental Protection Agency, access date June 29, 2010.United States Environmental Protection Agency (USEPA). Human health risk assessment model ecological risk assessment; 2017. Available:https://www.epa.gov/risk/humanhealth- risk-assessment\#self. 
USEPA, Exposure Factors Handbook: 2011 Edition, EPA/600/R- 090/052F, Office of Research and Development, Washington, DC, USA, 2011.

USEPA. Multimedia, multi-pathway and multi-receptor risk assessment (3MRA) modelling system. U.S Environmental Protection Agency, Office of Research and Development, Washington DC. 2002;1-9.

Uwimana, A., Nhapi, I., Wali, U.G. and Hoko, Z. (2010). Sludge Characterization at Kadahokwa Water Treatment Plant, Rwanda. Water Sci. Technolo. Water. Supply. 10(2): 1-16.

Velcheva, E., D. Tomova, D. Arnaudova and A. Arnaudov, 2010. Morphological investigation on gills and liver of fresh water fish from Dam Lake "StudenKladenets". Bulgarian Journal of Agriculture Sciences, 16(3): 364-368.

WHO, 1989. Lead: environmental aspects. Geneva, Environmental Health Criteria, No. 85.

WHO, 2001. Arsenic and Arsenic compounds: Environmental Health Criteria.Vol.224.Geneva: World Health Organization. International Program on Chemical Safety (IPCS), Geneva, Switzerland.

WHO, 2010. Guideline for Drinking Water Quality. $3^{\text {rd }}$ Edn., World Health Organization, Geneva, Switzerland.

WHO, world Health Organization, International standards of drinking water, Geneva, 2004, 5579.

WHO/FAO. (2016). Joint FAO/WHO Food Standard Programme Codex Alimentarius Commission 10th Session. Working document for information and use in discussions related to contaminants and toxins in the gsctff (Prepared by Japan and the Netherlands) 4 - 8 April 2016.

Yarsan E, Yipel M (2013). The important terms of marine pollution Biomarkers and biomonitoring, bioaccumulation, bioconcentration, biomagnification. J MolBiomarkDiagn S1

Zaqoot, H.A, Adnan, M. A. and Hisham, N. W. (2017). Baseline Concentration of Heavy Metals in Fish Collected from Gaza Fishing Harbor in the Mediterranean Sea along Gaza Coast, Palestine.Turkish Journal of Fisheries and Aquatic Sciences 17: 101-109DOI: 10.4194/13032712-v17_1_12 